\title{
Mengukur Kemampuan Keaksaraan Anak Usia Dini Melalui Instrumen Penilaian
}

\author{
Novy Dwi Mandasari1 ${ }^{*}$, I Ketut Gading 2 , Dewa Gede Firstia Wirabrata ${ }^{3}$ \\ 1,3 Pendidikan Guru Pendidikan Anak Usia Dini, Universitas Pendidikan Ganesha, Singaraja, Indonesia \\ ${ }^{2}$ Bimbingan dan Konseling, Universitas Pendidikan Ganesha, Singaraja, Indonesia
}

\section{ART I CLE INFO}

Article history:

Received 12 January 2021

Revised 15 February 2021

Accepted 05 April 2021

Available online 25 April 2021

\section{Kata Kunci:}

Kemampuan Keaksaraan,

Instrumen, Penilaian

Keywords:

Literacy Skills, Instrumens, Appraisal

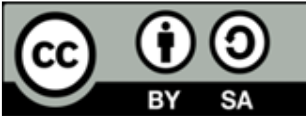

This is an open access article under the CC BY-SA license.

Copyright @ Universitas Pendidikan Ganesha. All rights reserved.

\begin{abstract}
A B S T R A K
Guru yang kesulitan membuat instrumen penilaian pada anak usia dini. Selain itu tidak ada instrumen penilaian yang mengukur kemampuan keaksaraan awal pada anak. Penelitian ini bertujuan untuk mengembangkan instrumen penilaian keaksaraan awal pada anak usia dini. Penelitian ini adalah penelitian pengembangan. Model yang digunakan pada penelitian ini yaitu 4D. Teknik yang digunakan dalam mengumpulkan data yaitu observasi, wawancara, dan kuesioner. Instrumen yang digunakan dalam mengumpulkan data yaitu kuesioner. Uji validitas instrumen penilaian keaksaran pada penelitian ini dilakukan melalui uji validitas isi (uji ahli/pakar). Instrumen yang dikembangkan akan diuji oleh 2 orang ahli. Subjek uji coba penelitian berjumlah 30 siswa. Uji reliabilitas instrumen pengukuran kemampuan keaksaraan awal menggunakan rumus Alpha Cronbacth. Hasil penelitian yaitu berdasarkan hasil penilaian yang dilakukan oleh ahli materi pelajaran mendapatkan kategori sangat tinggi. Hasil uji coba instrumen mendapatkan kategori sangat tinggi. Hasil uji validitas dan reliabilitas instrumen juga mendapatkan kategori sangat tinggi. Jadi dapat disimpulkan abahwa instrumen pengukuran kemampuan keaksaraan awal yang telah dikembangkan valid dan realible. Implikasi penelitian ini yaitu instrumen yang telah dikembangkan dapat digunakan oleh guru dalam mengukur kemampuan keaksaraan pada anak usia dini.
\end{abstract}

\section{A B S T RA C T}

Teachers who have difficulty making assessment instrumens in early childhood. In addition, there is no assessment instrumen that measures early literacy skills in children. This study aims to develop an instrumen for assessing early literacy in early childhood. This research is development research. The model used in this study is $4 D$. The techniques used in collecting data are observation, interviews, and questionnaires. The instrumen used in collecting data is a questionnaire. The validity test of the literacy assessment instrumen in this study was carried out through a content validity test (expert/expert test). The instrumen developed will be tested by 2 experts. The subjects of the research trial were 30 students. The reliability test of the initial literacy ability measurement instrumen used the Alpha Cronbact formula. The results of the study are based on the results of assessments carried out by subject matter experts to get a very high category. The results of the instrumen trial get a very high category. The test results of the validity and reliability of the instrumen also get a very high category. So it can be concluded that the instrumen for measuring early literacy ability that has been developed is valid and reliable. The implication of this research is that the instrumens that have been developed can be used by teachers in measuring literacy skills in early childhood.

\section{Pendahuluan}

Anak usia disebut sebagai masa emas (golden age). Hal ini disebabkan karena pada masa ini anak mengalami perkembabangan yang paling cepat, sehingga awal ini juga menjadi penentu bagi perkembangan selanjutnya (Fitri, Saparahayuningsih, \& Agustriana, 2017; Manurung, Wulan, \& Purwanto, 2021). Dalam hal ini pada masa ini sangatlah penting untuk menstimulasi perkembangan dan pertumbuhan anak, salah satunya dengan memberikan pelayanan pendidikan. Untuk mencipkan anak

Copyright (c) Universitas Pendidikan Ganesha. All rights reserved 
yang berkualitas, pendidikan harus dilaksanakan sejak usia dini melalui pendidikan anak usia dini (Agustin, Inten, Permatasari, \& Mulyani, 2021; Sari \& Setiawan, 2012; Suastariyani \& Tirtayani, 2019). Tujuan pendidikan anak usia dini yaitu membina anak melalui pemberian rangsangan pendidikan agar anak memiliki kesiapan untuk memasuki pendidikan yang lebih lanjut (Dewi, Tirtayani, \& Suniasih, 2019; Shofa, 2018). Dalam pendidikan anak usia akan mengembangkan enam aspek dalam proses pembelajaran untuk menstrimulasi perkembangan anak. Aspek tersebut yaitu motorik, bahasa, kognitif, ninai moral, dan sosial emosional (Fauziddin, 2015; Meilinda, 2020). Salah satu aspek yang penting untuk dikembangkan yaitu aspek bahasa. Bahasa dapat dijadikan sebuat alat komunikasi bagi anak usia dini (Suyeni, Wirya, \& Ujianti, 2016; Triutami, Sudhita, \& Tegeh, 2014). Melalui pendidikan diharapkan anak memiliki kemampuan bahasa yang baik.

Namun, permasalahan yang terjadi saat ini yaitu masih banyak anak yang memiliki kemampuan bahasa yang kurang (Aulia \& Budiningsih, 2021; Suardi, Ramadhan, \& Asri, 2019). Hal ini disebabkan karena proses pembelajaran yang kurang berjalan secara maksimal. Selain itu, masih banyak sekolah yang tidak memiliki instrumen penilaian kemampuan bahasa (Kurnia, Taufiq, \& Silawati, 2015; Simanjuntak, Akbar, \& Mudiono, 2019). Permasalahan ini juga ditemukan pada salah satu taman kanak-kanak. Berdasakan hasil observasi dan wawancara yang dilakukan di TK Kartika VII-3 dan TK Eka Dharma Singaraja, ditemukan permasalahan yaitu tidak ada instrumen pengukuran kemampuan keaksaraan awal anak pada kelompok B. Selama ini juga hanya membuat instrumen dari keseluruhan enam aspek perkembangan. Selain itu guru juga hanya memberikan penilaian secara langsung kepada siswa. Di sekolah juga tidak terdapat pelatihan pembuatan instrumen bagi guru. Guru hanya mengikuti pelatihan kurikulum, RPPH, dan RPPM sehingga belum mampu membuat instrumen yang valid dan reliable. Berdasarkan permasalahan ini dapat disimpulkan bahwa tidak ada instrumen khusus yang valid dan reliable untuk mengukur keaksaraan anak. Jika permasalahan ini dibiarkan maka akan berdampak pada pencapaian pembelajaran yang kurang maksimal. Kemampuan keaksaraan pada anak tidak dapat terukur dengan baik sehingga guru tidak dapat mengetahui keberhasilan proses pembelajaran.

Berdasarkan permasalahan tersebut, maka solusi untuk memecahkan masalah tersebut yaitu dengan mengembangkan instrumen penilaian untuk keaksaraan anak. Instrumen yang akan dikembangkan akan mengukur kemampuan anak usia dini. Kemampuan merupakan kapasitas anak dalam hal kesanggupan, kecakapan, serta kekuatan untuk melaksanakan kegiatan dengan usahanya sendiri (Ginting, Purwanto, \& Faradillah, 2019; Yuliani \& Noto, 2018). Dalam pembelajaran, instrumen merupakan unsur terpenting yang harus dimiliki oleh guru (Candra, Sulistya, \& Prasetyo, 2018a; Gaol, Khumaedi, \& Masrukan, 2017). Hal ini disebabkan karena instrumen dapat mengukur kemampuan atau perkembangan seorang anak terutama untuk mengukur keaksaraan anak usia dini. Instrumen dikatakan baik jika memenuhi syarat penting yaitu valid dan reliable (Candra et al., 2018a; Yusup, 2018). Instrumen akan memudahkan guru dalam mengukur tingkat keberhasilan siswa (Adjii, 2019; Afrita \& Darussyamsu, 2020; Novitasari \& Wardani, 2020; Zuliani, Florentinus, \& Ridlo, 2017). Instrumen juga dapat digunakan oleh guru untuk mengevaluasi metode pembelajaran yang digunakan saat kegiatan pembelajaran. Selain itu, instrumen juga dapat menjadi bahan umpan balik bagi guru serta siswa. Instrumen penilaian keaksaraan yang akan dikembangkan nantinya digunakan sebagai alat evaluasi yang memiliki beberapa teknik. Ketepatan dalam menggunakan instrumen dalam evaluasi akan menentukan hasil yang diperoleh. Ketepatan antara yang diukur dengan alat ukur sangat diperlukan sehingga tidak terjadi kesalahan ketika membuat suatu keputusan ataupun kesimpulan. Jadi dapat disimpulkan bahwa instrumen sangat penting untuk mengukur tingkat keberhasilan anak dalam pembelajaran terutama pada keaksaraan awal.

Keaksaraan awal termasuk dalam pembelajaran pada anak usia dini. Keaksaraan awal merupakan kemampuan dasar membaca dan menulis, serta pengenalan huruf vokal dan konsonan pada anak usia dini (Amini, 2016; Listriani, Hapidin, \& Sumadi, 2021). Kemampuan ini sangat penting dibangun sejak dini karena akan mempengaruhi perkembangan dan pribadi anak. Keaksaraan ini merupakan salah satu bentuk keterampilan bahasa. Fokus utama dalam pengenalan keaksaraan pada anak yaitu mengenal gambar yang diwakilkan dengan huruf. Mengenal keaksaraan awal ini berarti kemampuan anak untuk mengenali huruf vokal serta konsonan sebagai kemampaun dasar yang wajib dikuasi oleh anak untuk membaca serta menulis (Borre, Bernhard, Bleiker, \& Winsler, 2019; Christianti, 2013). Tujuan utama mengenal keaksaraan yaitu sebagai persiapan dalam membaca dan menulis (Darnis, 2018; Maqdalena \& Widiastuti, 2018). Selain itu, tujuan mengenal keaksaraan yaitu mengenalkan anak pada huruf dalam abjad, melatih keterampilan anak dalam mengubah huruf menjadi suara, dan keterampilan menyuarakan yang dapat dipraktekan ketika anak belajar membaca lanjut (Agustini, Masudah, \& Rofiqoh, 2020). Jadi mengenal keaksaraan sangat penting dilakukan bagi anak usia dini sehingga anak dengan mudah belajara membaca dan menulis. Temuan penelitian sebelumnya mengenai instrumen menyatakan bahwa instrumen penilaian sangat penting dimiliki oleh guru untuk mengukur keberhasilan siswa dalam belajar (Agustin et al., 2021; Hulukati \& Rahmi, 2020). Penelitian lainnya juga menyatakan bahwa instrumen 
penelitian dapat digunakan untuk mengukur hasil belajar siswa (Asyhari, 2019; Khaerunnnisa \& Pamungkas, 2019). Jadi dapat disimpulkan bahwa instrumen sangat diperlukan untuk mengukur kemampuan ataupun hasil belajar anak.

Kelemahan dari instrumen yang telah dikembangkan sebelumnya yaitu instrumen hanya mengukur kemampuan kognitif siswa sehingga kemampuan siswa pada aspek bahasa belum terukur dengan baik. Selain itu, belum adanya kajian mengenai pengembangan instrumen penilaian keaksaraan bagi anak usia dini. Kelebihan instrumen yang akan dikembangkan yaitu setiap butir instrumen disesuaikan dengan indikator pembelajaran sehingga memudahkan dalam melakukan pengukuran keaksaraan awal pada siswa. Selain itu, instrumen ini juga dibuat berdasarkan teori keaksaraan awal anak usia dini sehingga instrumen yang dikembangkan valid dan sesuai. Instrumen yang telah dikembangkan dapat digunakan oleh guru untuk mengukur keaksaraan awal bagi anak usia dini. Tujuan penelitian ini yaitu untuk mengembangan instrumen penilaian keaksaraan bagi anak usia dini. Adannya instrumen yang layak diharapkan akan mampu mengukur keaksaraan awal pada anak usia dini.

\section{Metode}

Jenis penelitian ini yaitu penelitian pengembangan. Prosedur atau model yang digunakan dalam penelitian ini yaitu model 4D terbagi atas empat tahap yaitu Define, Design, Develop, dan Disseminate (Agung, 2014). Model ini digunakan karena sifatnya yang sistematis serta mudah dipahami. Subyek penelitian ini adalah instrumen keaksaraan untuk anak usia dini. Sebagai subjek penelitian instrumen ini akan diujikan kepada ahli yang terdiri dari 2 orang ahli bidang studi dan ahli pengukuran. Subjek uji coba penelitian yaitu siswa kelompok B TK Kartika VII-3 Singaraja dan TK Eka Dharma Singaraja yang berjumlah 30 siswa. Teknik yang digunakan dalam mengumpulkan data yaitu observasi, wawancara dan kuesioner. Observasi dan wawancara dilakukan untuk mengetahui informasi mengenai permasalahan yag sedang terjadi pada anak usia dini saat mengikuti proses pembelajaran. Kuesioner digunakan mengetahui tanggapan praktisi dan guru mengenai instrumen penilaian yang telah dikembangkan. Instrumen yang digunakan dalam mengumpulkan data adalah kuesioner. Setelah instrumen divalidasi oleh ahli, kemudian data akan dianalisis dengan memasukkan skor hasil uji ahli ke dalam tabel tabulasi silang. Mengukur validitas dalam penelitian ini menggunakan rumus Gregory. Dalam mengukur validitas butir digunakan korelasi Product Moment. Uji reliabilitas instrumen pengukuran kemampuan keaksaraan awal menggunakan rumus Alpha Cronbacth.
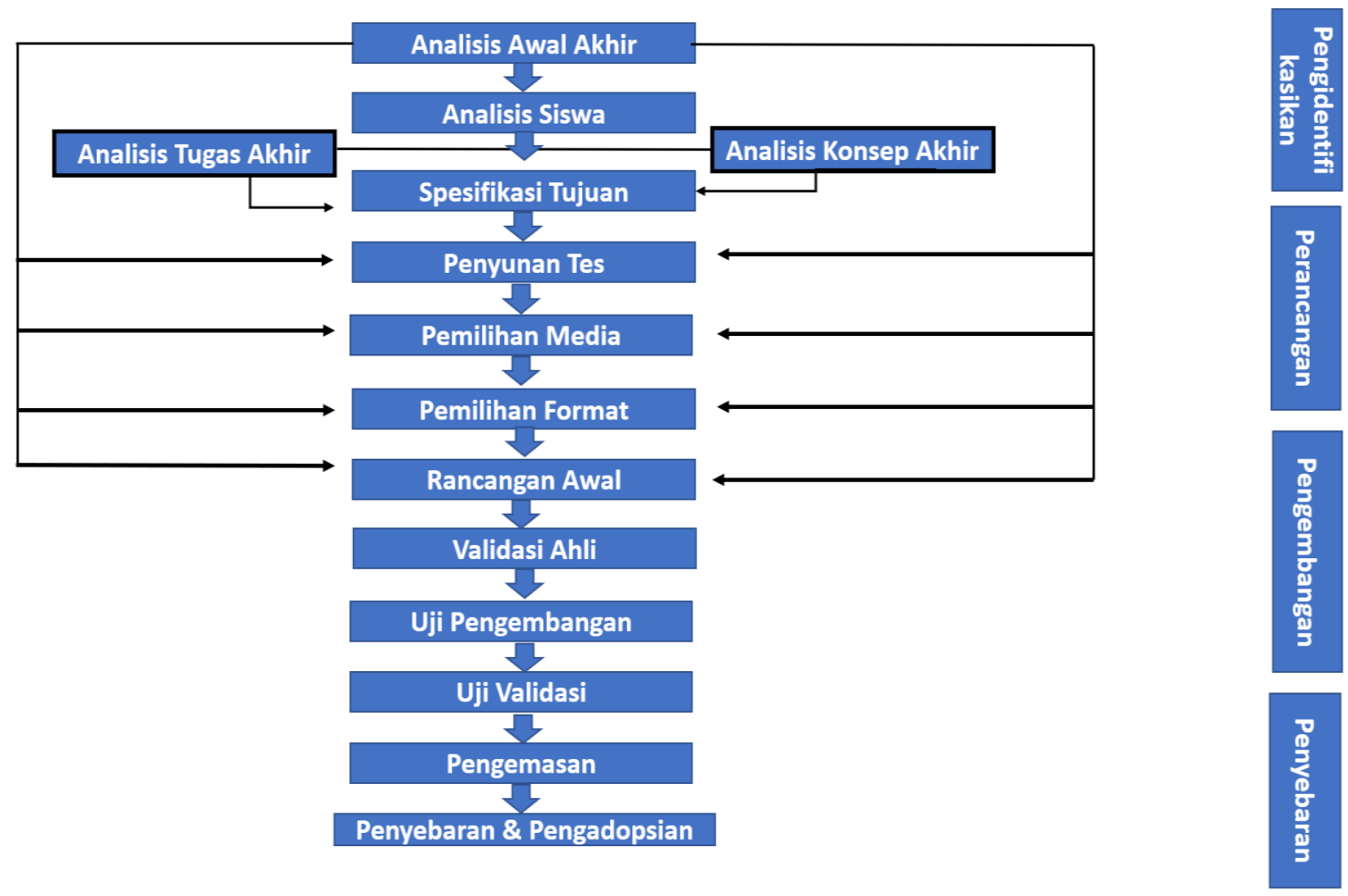

Gambar 1. Rancangan Penelitian Menggunakan Model 4D 


\section{Hasil dan Pembahasan}

Tahapan pengembangan instrumen keaksaraan yang digunakan dalam penelitian yaitu model 4D terbagi atas empat tahap yaitu Define, Design, Develop, dan Disseminate. Namun pada tahapan penyebaran (disseminate) tidak terlaksana disebabkan karena keterbatasan waktu, tenaga sumber daya, finansial dan anak masih belajar dari rumah dikarenakan pandemi COVID-19. Adapun pemaparan tahapan pengembangan yaitu sebagai berikut. Tahap pertama yaitu pendefinisian (define). Kegiatan yang dilakukan yaitu analisis kebutuhan, analisis karakteristik siswa dan analisis tugas. Hasil analisis kebutuhan menunjukkan bahwa perlu adanya instrumen pengukuran kemampuan keaksaraan awal anak kelompok B Taman Kanak-Kanak. Hasil analisis karakteristik siswa menunjukkan bahwa siswa dalam pembelajaran keaksaraan awal kurang optimal dikarenakan tidak adanya instrumen pengukurang keaksaraan awal. Hasil analisis tugas Hasil analisis tugas menunjukkan bahwa anak-anak kelompok B hanya diberikan LKPD (Lembar Kerja Peserta Didik) untuk pembelajaran keaksaraan awal contohnya seperti menebalkan huruf dan melengkapi huruf. Tahap kedua yaitu perancangan. Pada tahap perancangan (design) dilakukan dengan membuat design awal instrumen pengukuran kemampuan keaksaraan awal. Pada tahap ini mengumpulkan informasi mengenai materi yang berkaitan dengan keaksaraan awal. Hal ini bertujuan untuk membuat perencanaan produk instrumen pengukuran kemampuan keaksaraan awal anak. Produk yang direncanakan disesuaikan dengan materi keaksaraan awal. Setelah perencanaan desain materi sudah tergambar dan sesuai dengan pembelajaran yang ada, kegiatan selanjutnya yaitu penyesuaian item-item yang diperoleh dari berbagai sumber yang digunakan dalam penelitian ini. Tahap ini dilakukan diskusi dengan dosen PG PAUD agar instrumen tersebut yang telah disusun dapat tepat sasaran. Adapun kisi-kisi instrumen yang telah dikembangkan tersaji pada Tabel 1.

Tabel 1. Kisi-Kisi Instrumen Pengukuran Kemampuan Keaksaraan Awal

\begin{tabular}{|c|c|c|}
\hline Variabel & Dimensi & Indikator \\
\hline \multirow{5}{*}{$\begin{array}{l}\text { Kemampuan } \\
\text { Keaksaraan } \\
\text { Awal }\end{array}$} & Membaca huruf & $\begin{array}{l}\text { Menirukan bunyi huruf awal yang sama pada kelompok } \\
\text { gambar } \\
\text { Menunjukkan simbol-simbol huruf }\end{array}$ \\
\hline & $\begin{array}{l}\text { Mengetahui hubungan } \\
\text { antara bunyi dan bentuk } \\
\text { huruf }\end{array}$ & $\begin{array}{l}\text { Membedakan hubungan antara bunyi dan bentuk huruf } \\
\text { Menanyakan suara huruf dari nama benda-benda } \\
\text { disekitarnya }\end{array}$ \\
\hline & Mengenal huruf & Membaca nama sendiri \\
\hline & \multirow{2}{*}{$\begin{array}{l}\text { Menunjukkan } \\
\text { kemampuan keaksaraan } \\
\text { awal dalam berbagai } \\
\text { bentuk karya }\end{array}$} & $\begin{array}{l}\text { Menuliskan nama sendiri } \\
\text { Menuliskan huruf atau kata yang ada pada kartu atau } \\
\text { huruf }\end{array}$ \\
\hline & & Menemukan huruf-huruf dari kartu kata \\
\hline
\end{tabular}

Tahap ketiga yaitu pengembangan (development). Pada tahap ini dilakukan pengembangan instrumen keaksaraan awal pada anak usia dini. Adapun instrumen keaksaraan awal pada anak usia dini tersaji pada Tabel 2.

Tabel 2. Instrumen Penilaian oleh Ahli Isi Pelajaran

\begin{tabular}{cl}
\hline No & \multicolumn{1}{c}{ Aspek yang Dinilai } \\
\hline 1 & Kesesuaian Indikator dengan konsep variabel \\
2 & Kesesuaian item dengan indikator \\
3 & Membedakan satu bunyi huruf dengan lainnya (m dan $\mathrm{n}, \mathrm{l}$ dan $\mathrm{r}, \mathrm{a}$ dan $\mathrm{h}, \mathrm{f}$ dan $\mathrm{v}, \mathrm{p}$ dan $\mathrm{v}$ ) \\
4 & Menirukan kata yang mempunyai fonem yang sama misalnya (susu, susi) \\
5 & Menunjukkan huruf a-z \\
6 & Menunjukkan huruf vokal (a, i, u, e, o) \\
7 & Menunjukkan huruf konsonan (b, c, d, f, g, h, j, k, l, $\mathrm{m}, \mathrm{n}, \mathrm{p}, \mathrm{q}, \mathrm{r}, \mathrm{s}, \mathrm{t}, \mathrm{v}, \mathrm{w}, \mathrm{x}, \mathrm{y}, \mathrm{z}$ ) \\
8 & Membedakan huruf dari sebuah kartu bergambar \\
9 & Membaca gambar yang memiliki kata dan kalimat sederhana \\
10 & Menyusun huruf menjadi sebuah kata seperti (I-b-u) \\
11 & Menunjukkan huruf sesuai dengan bunyinya \\
12 & Mengelompokkan huruf vokal atau konsonan pada suku kata sambil menyebutkan bunyi huruf \\
13 & Membaca kata dengan lengkap
\end{tabular}




\begin{tabular}{cl}
\hline No & \multicolumn{1}{c}{ Aspek yang Dinilai } \\
\hline 14 & Membaca dan menunjukkan nama sendiri \\
15 & Menunjukkan simbol huruf \\
16 & Membuat gambar dengan berbagai coretan atau tulisan yang sudah berbentuk huruf atau kata \\
17 & Menyusun suku kata menjadi kata menggunakan kartu kata \\
18 & Membaca huruf dari kartu kata \\
\hline
\end{tabular}

Setelah dilakukan pengembangan instrumen keaksaraan awal, langkah selanjutya yaitu penilaian ahli dan uji pengembangan produk (developmental testing). Pada tahap penilaian ahli dilaksanakan validasi terhadap instrumen penilaian yang dilakukan oleh dosen ahli. Berdasarkan penilaian yang dilakukan oleh ahli isi pelajaran. Hasil hitung validitas instrumen pengukuran kemampuan keaksaraan awal mendapatkan nilai 1 sehingga berada pada kriteria sangat tinggi. Jumlah instrumen yang valid sebanyak 18, dengan persentase instrumen valid yaitu 100\% (sangat tinggi). Berdasarkan uji coba yang telah dilakukan dengan jumlah peserta uji coba, $\mathrm{N}=30$ dan taraf signifikasi $5 \%$ didapatkan $\mathrm{r}_{\text {tabel }}=0,361$. Kriteria butir instrumen dinyatakan valid jika $r_{x y}$ hitung lebih besar daripada $r_{x y}$ tabel $\left(r_{x y}\right.$ hit $>r_{x y}$ tabel). Dapat disimpulkan bahwa seluruh nomor instrumen valid. Setelah dilakukan uji validitas dilaksanakan, selanjutnya dilaksanakan uji reliabilitas pada instrumen. Berdasarkan hasil perhitungan diperoleh nilai $r_{11}$ sebesar 0,93. Sehingga dapat disimpulkan bahwa instrumen pengukuran kemampuan keaksaraan awal dalam penelitian ini dapat dikatan reliabel karena nilai koefisien reliabilitas yang diperoleh lebih besar dari 0,60. Berdasarkan hasil analisis data maka dapat disimpulkan bahwa instrumen pengukuran kemampuan keaksaraan awal yang telah dikembangkan valid dan reliable. Instrumen yang telah dikembangkan dapat digunakan untuk mengukur kemampuan keaksaraan awal siswa. Hal tersebut disebabkan oleh beberapa faktor yaitu sebagai berikut.

Pertama, instrumen penilaian kemampuan keaksaraan awal pada siswa valid dan layak digunakan karena telah memenuhi syarat instrumen yang baik. Instrumen menjadi layak digunakan dan berkualitas jika dalam pengembangannya menggunakan prosedur pengadaan instrumen yang benar (Candra et al., 2018a; Zuliani et al., 2017). Instrumen penilaian kemampuan keaksaraan awal dikembangkan berdasarkan hasil analisis yang telah dilakukan sebelumnya. Setiap butir instrumen penilaian dikembangkan menyesuaikan dengan indikator pembelajaran dan berdasarkan teori keaksaraan awal pada anak usia dini sehingga instrumen yang dikembangkan sesuai dan valid. Syarat dari sebuah penilaian yang baik yaitu valid, praktis, dan reabilitas. Prinsip dasar yang wajib dipenuhi dalam penilaian siswa yaitu berkesinambungan, valid, mendidik, menyeluruh, bermakna serta berorientasi pada kompetensi siswa (Hulukati \& Rahmi, 2020; Novitasari \& Wardani, 2020). Selain itu, instrumen yang dikembangkan dalam penelitian ini juga telah melakukan revisi instrumen yang diterima oleh masukan dari para ahli sehingga instrumen penilaian kemampuan keaksaraan awal menjadi sempurna.

Kedua, instrumen penilaian kemampuan keaksaraan awal pada siswa valid dan layak digunakan karena instrumen ini dapat mengukur kemampuan keaksaraan awal pada anak sehingga memperoleh informasi yang diinginkan. Instrumen yang dikembangkan pada penelitian ini menyesuaikan dengan materi yang digunakan di taman kanak-kanak sehingga dapat digunakan oleh guru dalam mengukur kemampuan keaksaraan awal siswa. Instrumen yang baik dapat mengukur informasi yang ingin didapatkan (Arif, 2016; Nugraha, 2017; Wildan, 2017). Selain itu penyusunan item-item instrumen keaksaraan ini diperoleh dari berbagai sumber sehingga membuat instrumen berkualitas. Dalam menyusun sebuah instrumen juga diperlukan sumber yang disesuaikan dengan pengembangan instrumen yang akan dilakukan (Damanik \& Setiawan, 2016; Darmansyah, 2014; Sari \& Setiawan, 2012). Instrumen merupakan alat ukur yang dapat digunakan dalam menilai sesuatu sehingga memperoleh informasi yang diinginkan (Candra, Sulistya, \& Prasetyo, 2018b; Gaol et al., 2017). Penilaian ini wajib dilakukan untuk mengetahui informasi kemampuan keaksaraan awal pada anak usia dini secara berkala. Penilaian juga dapat dilakukan dengan tes. Penggunaan tes juga bertujuan untuk mengukur ketercapaian siswa dalam belajar (Adjii, 2019; Yusup, 2018). Dalam hal ini guru sangat memerlukan instrumen penilaian untuk mengetahui perkembangan siswa. Pada penelitian ini, pengembangan instrumen kemampuan keaksaraan awal pada anak berada pada kriteria sangat tinggi sehingga layak digunakan sebagai alat evaluasi pembelajaran yang akurat pada aspek bahasa untuk anak usia dini.

Temuan penelitian sebelumnya juga menyatakan bahwa instrumen yang baik dapat mengukur kemampuan siswa (Umami, Rusdi, \& Kamid, 2021). Temuan penelitian lainnya juga menyakan bahwa instrumen layak digunakan jika telah valid dan reliabel sehingga dapat mengukur kemampuan siswa (Arif, 2016; Astuti \& Darsinah, 2018; Sukanti, 2011). Sehingga dapat disimpulkan instrumen yang baik yaitu telah memenuhi syarat sehingga dapat digunakan untuk mengukur kemampuan anak. Implikasi penelitian ini yaitu instrumen yang telah dikembangkan berupa instrumen kemampuan keaksaraan awal dapat digunakan oleh guru untuk mengukur kemampuan keaksaraan pada anak usia dini. Selain itu, instrumen 
ini juga dapat dijadikan contoh dalam mengembangkan instrumen lainnya. Dengan adanya instrumen ini akan membantu guru mengetahui tingkat kemampuan keaksaraan pada anak usia dini.

\section{Simpulan}

Berdasarkan hasil analisis data disimpulkan bahwa Instrumen penilaian kemampuan keaksaraan telah memenuhi kriteria valid, reliabel serta memiliki kualitas yang baik. Dapat disimpulkan bahwa instrumen kemampuan keaksaraan awal valid dan layak digunakan sebagai instrumen penilaian pada anak usia dini. Instrumen penilaian yang telah dikembangkan cocok digunakan dalam menilai kemampuan keaksaraan pada anak usia dini. Instrument ini juga membantu guru untuk mengetahui tingkat keberhasilan atau pemahaman siswa selama mengikuti pembelajaran di kelas.

\section{Daftar Rujukan}

Adjii, K. (2019). Instrumen penilaian kedisiplinan siswa sekolah menengah kejuruan. Assessment and Research on Education, 1(1). https://doi.org/http://dx.doi.org/10.33292/arisen.v1i1.19.

Afrita, M., \& Darussyamsu, R. (2020). Validitas Instrumen Tes Berpikir Tingkat Tinggi (HOTS) pada Materi Sistem Respirasi di Kelas XI SMA. Jurnal Mangifera Edu, 4(2). https://doi.org/https://doi.org/10.31943/mangiferaedu.v4i2.83.

Agung, A. A. G. (2014). Metodologi Penelitian Pendidikan. Singaraja: ADITYA MEDIA.

Agustin, M., Inten, D. N., Permatasari, A. N., \& Mulyani, D. (2021). Strategi Guru PAUD dalam Mengembangkan Kecerdasan Interpersonal Anak Usia Dini di Saat Belajar dari Rumah. Jurnal Obsesi: Jurnal Pendidikan Anak Usia Dini, 5(2). https://doi.org/https://doi.org/10.31004/obsesi.v5i2.1055.

Agustini, Masudah, \& Rofiqoh, D. (2020). Pengaruh Media Dadu Putar Terhadap Kemampuan Keaksaraan Anak Kelompok B. Jurnal Jurnal PAUD Teratai, 9(1). https://doi.org/http://dx.doi.org/10.24235/awlady.v3i1.1278.

Amini. (2016). Meningkatkan Kemampuan Keaksaraan Reseptif Anak Melalui Permainan Pola Suku Kata Di Taman Kanak- Kanak Negeri Pembina Yogyakarta. Jurnal Pendidikan Anak, 5(1). https://doi.org/https://doi.org/10.21831/jpa.v5i1.12362.

Arif, M. (2016). Pengembangan Instrumen Penilaian Mapel Sains melalui Pendekatan Keterampilan Proses Sains SD/MI. Ta'allum: Jurnal Pendidikan Islam, 4(1). https://doi.org/https://doi.org/10.21274/taalum.2016.4.1.123-148.

Astuti, S. I., \& Darsinah, D. (2018). Penilaian Autentik Berbasis Kurikulum 2013 di SD Negeri Mangkubumen Kidul No. 16 Surakarta. Manajemen Pendidikan, 13(2), 165-174. https://doi.org/10.23917/jmp.v13i2.7484.

Asyhari, A. (2019). Pengembangan Instrumen Asesmen Literasi Sains Berbasis Nilai-Nilai Islam Dan Budaya Indonesia Dengan Pendekatan Kontekstual. Lentera Pendidikan : Jurnal Ilmu Tarbiyah Dan Keguruan, 22(1). https://doi.org/https://doi.org/10.24252/lp.2019v22n1i14.

Aulia, B. N. R., \& Budiningsih, C. A. (2021). Tingkat Pemahaman Guru Taman Kanak-kanak di Lombok dalam Stimulasi Pengembangan Bahasa Anak Usia Dini. Jurnal Obsesi : Jurnal Pendidikan Anak Usia Dini, 5(1). https://doi.org/https://doi.org/10.31004/obsesi.v5i2.1082.

Borre, Bernhard, Bleiker, \& Winsler. (2019). Preschool Literacy Intervention for Low-Income , Ethnically Diverse Children : Effects of the Early Authors Program Through Kindergarten Preschool Literacy Intervention for Low-Income. Journal of Education for Students Placed at Risk (JESPAR), 24(2). https://doi.org/https://doi.org/10.1080/10824669.2019.1594818.

Candra, I., Sulistya, N., \& Prasetyo, T. (2018a). Pengembangan Instrumen Sikap Sosial Tematik Siswa SD Kelas IV. Jurnal Ilmiah Sekolah Dasar Undiksha, 2(4). https://doi.org/http://dx.doi.org/10.23887/jisd.v2i4.16167.

Candra, I., Sulistya, N., \& Prasetyo, T. (2018b). Pengembangan Instrumen Sikap Sosial Tematik Siswa SD Kelas IV. Jurnal Ilmiah Sekolah Dasar, 2(4), 455. https://doi.org/10.23887/jisd.v2i4.16167.

Christianti, M. (2013). Membaca dan Menulis Permulaan Untuk Anak Usia Dini. Jurnal Pendidikan Anak, 2(2). https://doi.org/https://doi.org/10.21831/jpa.v2i2.3042.

Damanik, M. R., \& Setiawan, D. (2016). Pengembangan Penilaian Autentik Berbasis Karakter Pada Ranah Keterampilan Di Fakultas Ilmu Sosial Universitas Negeri Medan. Jurnal Pendidikan Ilmu-Ilmu Sosial, 8(2). https://doi.org/https://doi.org/10.24114/jupiis.v8i2.5150.

Darmansyah, D. (2014). Teknik Penilaian Sikap Spritual dan Sosial dalam Pendidikan Karakter di Sekolah Dasar 08 Surau Gadang Nanggalo. Al-Ta Lim Journal, 21(1), 10-17. https://doi.org/10.15548/jt.v21i1.67. 
Darnis. (2018). Aplikasi Montessori Dalam Pembelajaran Membaca, Menulis Dan Berhitung Tingkat Permulaan Bagi Anak Usia Dini. Jurnal Caksana: Pendidikan Anak Usia Dini, 1(1). https://doi.org/https://doi.org/10.31326/jcpaud.v1i01.3.

Dewi, N. P. A. S., Tirtayani, L. A., \& Suniasih, N. W. (2019). Efektivitas Program Paud Inklusi Di Kota Denpasar Ditinjau Dari Aspek Konteks. Jurnal Pendidikan Anak Usia Dini Undiksha, 7(1). https://doi.org/http://dx.doi.org/10.23887/paud.v7i1.18731.

Fauziddin. (2015). Peningkatan Kemampuan Matematika Anak Usia Dini Melalui Permainan Jam Pintar di Taman Kanak-Kanak Pembina Kec. Bangkinang Kota. Jurnal PAUD Tambusai, 1(1), 49-54. https://doi.org/https://doi.org/10.31004/obsesi.v1i1.55.

Fitri, Saparahayuningsih, \& Agustriana. (2017). Perencanaan Pembelajaran Kurikulum 2013 Pendidikan Anak Usia Dini. Jurnal Ilmiah Potensia, 2(1). https://doi.org/https://doi.org/10.33369/jip.2.1.113.

Gaol, P. L., Khumaedi, M., \& Masrukan, M. (2017). Pengembangan Instrumen Penilaian Karakter Percaya Diri pada Mata Pelajaran Matematika Sekolah Menengah Pertama. Journal of Research and Educational Research Evaluation,

$6(1)$. https://doi.org/https://doi.org/10.15294/jrer.v6i1.16209.

Ginting, E. B., Purwanto, S. E., \& Faradillah, A. (2019). Pengaruh Model Pembelajaran Creative Problem Solving (CPS) terhadap Kemampuan Berpikir Kreatif Matematis Siswa. Jurnal Gammath, 4(1), 1-8. https://doi.org/https://doi.org/10.31932/ve.v8i2.39.

Hulukati, W., \& Rahmi, M. (2020). Instrumen Evaluasi Karakter Mahasiswa Program Pendidikan Guru Pendidikan Anak Usia Dini. Jurnal Obsesi: Jurnal Pendidikan Anak Usia Dini, 4(2). https://doi.org/https://doi.org/10.31004/obsesi.v4i2.468.

Khaerunnnisa, E., \& Pamungkas, A. S. (2019). Pengembangan Instrumen Kecakapan Matematis Dalam Konteks Kearifan Lokal Budaya Banten Pada Materi Bangun Ruang Sisi Datar. Kreano Jurnal Matematika Kreatif-Inovatif, 9(1). https://doi.org/https://doi.org/10.15294/kreano.v9i1.11210.

Kurnia, D., Taufiq, M., \& Silawati, E. (2015). Analisis Capaian Perkembangan Bahasa Anak Usia Dini Dalam Kegiatan Pembelajaran Dengan Metode Learning Based Resources. Cakrawala Dini: Jurnal Pendidikan Anak Usia Dini, 6(2). https://doi.org/https://doi.org/10.17509/cd.v6i2.10520.

Listriani, A., Hapidin, H., \& Sumadi, T. (2021). Kemampuan Keaksaraan Anak Usia 5-6 Tahun dalam Penerapan Metode Spalding di TK Quantum Indonesia. Jurnal Obsesi : Jurnal Pendidikan Anak Usia Dini, 5(1). https://doi.org/https://doi.org/10.31004/obsesi.v5i1.680.

Manurung, A. K. R., Wulan, S., \& Purwanto, A. (2021). Permainan Outdoor dalam Membentuk Kemampuan Ketahanmalangan pada Anak Usia Dini. Jurnal Pendidikan Anak Usia Dini, 5(2), 1807-1814. https://doi.org/https://doi.org/10.31004/obsesi.v5i2.1030.

Maqdalena, \& Widiastuti. (2018). Meningkatkan Kemampuan Simbol Huruf Melalui Permainan Ular Tangga Pada Anak Usia 5-6 Tahun Di Desa Dukuh Krajan Rt 09 Rw 01 Kelurahan Dukuh Kecamatan Sidomukti Kota Salatiga. Satya Widya: Jurnal Penelitian Pengembangan Pendidikan, 34(2). https://doi.org/https://doi.org/10.1017/CB09781107415324.004.

Meilinda. (2020). Implementasi Konsep Pengasuhan Dalam Upaya Meningkatkan Kemandirian Anak Usia Dini (Survei Di Desa Adat Serangan). Jurnal Pendidikan Anak Usia Dini Undiksha, 8(2), 121-129. https://doi.org/http://dx.doi.org/10.23887/paud.v8i2.25654.

Novitasari, L., \& Wardani, N. S. (2020). Pengembangan Instrumen Sikap Toleransi Dalam Pembelajaran Tematik Kelas 5 SD. Jurnal Penelitian Tindakan Kelas Dan Pengembangan Pembelajaran, 3(1). https://doi.org/http://dx.doi.org/10.31604/ptk.v3i1.41-52.

Nugraha, R. (2017). Evaluasi Penerapan Standar Penilaian Kurikulum 2013 Pada Kelas 4 Sekolah Dasar di Kecamatan Jambu. Jurnal Sekolah (JS), 2. https://doi.org/https://doi.org/10.24114/js.v2i1.9925.

Sari, K. M., \& Setiawan, H. (2012). Kompetensi Pedagogik Guru dalam Melaksanakan Penilaian Pembelajaran Anak Usia Dini. Jurnal Obsesi: Jurnal Pendidikan Anak Usia Dini, 4(2). https://doi.org/https://doi.org/10.31004/obsesi.v4i2.478.

Shofa, M. F. (2018). Implementasi Manajemen Pendidikan Inklusi di PAUD Inklusi Saymara Kartasura. IAN Surakarta, 3(2). https://doi.org/https://dx.doi.org/10.22515/attarbawi.v3i2.1337.

Simanjuntak, I. A., Akbar, S., \& Mudiono, A. (2019). Asesmen Formatif Perkembangan Bahasa Anak. Jurnal Pendidikan: Teori, Penelitian, \& Pengembangan, 8(4). https://doi.org/http://dx.doi.org/10.17977/jptpp.v4i8.12686.

Suardi, I. P., Ramadhan, S., \& Asri, Y. (2019). Pemerolehan Bahasa Pertama pada Anak Usia Dini. Jurnal Obsesi: Journal of Early Childhood Education, 3(1). https://doi.org/https://doi.org/10.31004/obsesi.v3i1.160.

Suastariyani, N. K. N., \& Tirtayani, L. A. (2019). Survei Persepsi Orang Tua Mengenai Program Paud Inklusidi Kota Denpasar Tahun 2020. Jurnal Pendidikan Anak Usia Dini Undiksha, 8(2). 
https://doi.org/http://dx.doi.org/10.23887/paud.v8i2.25156.

Sukanti. (2011). Penilaian Afektif Dalam Pembelajaran Akuntansi. Jurnal Pendidikan Akutansi Indonesia, 9(1). https://doi.org/https://doi.org/10.21831/jpai.v9i1.960.

Suyeni, P. W., Wirya, N., \& Ujianti, P. R. (2016). Penerapan Metode Demonstrasi Melalui Permainan Tradisional Magoak-Goakan Untuk Meningkatkan Kemampuan Kerjasama. Jurnal Pendidikan Anak Usia Undiksha, 4(2). https://doi.org/http://dx.doi.org/10.23887/paud.v4i2.7805.

Triutami, I. G. A. A. D., Sudhita, I. W. R., \& Tegeh, I. M. (2014). Penerapan Metode Bercerita Berbantuan Media Boneka Tangan Untuk Meningkatkan Perkembangan Bahasa Pada Anak. Jurnal Pendidikan Anak Usia Dini, 2(1). https://doi.org/http://dx.doi.org/10.23887/paud.v2i1.3239.

Umami, R., Rusdi, M., \& Kamid, K. (2021). Pengembangan Instrumen Tes Untuk Mengukur Higher Order Thinking Skills (Hots) Berorientasi Programme For International Student Asessment (Pisa) Pada Peserta Didik. JP3M: Jurnal Penelitian Pendidikan Dan Pengajaran Matematika, 7(1). https://doi.org/https://doi.org/10.37058/jp3m.v7i1.2069.

Wildan, W. (2017). Pelaksanaan Penilaian Autentik Aspek Pengetahuan, Sikap Dan Keterampilan Di Sekolah Atau Madrasah. Jurnal Tatsqif, 15(2), 131-153. https://doi.org/10.20414/jtq.v15i2.3.

Yuliani, \& Noto, M. S. (2018). Pengaruh Model Pembelajaran Missouri Mathematics Project Terhadap Kemampuan Koneksi Matematis dan Kemandirian Belajar Siswa SMP. Jurnal Elemen, 4(2). https://doi.org/https://doi.org/10.29408/jel.v4i2.478.

Yusup, F. (2018). Uji Validitas dan Reliabilitas Instrumen Penelitian Kuantitatif. Jurnal Tarbiyah : Jurnal Ilmiah Kependidikan, $7(1)$ $17-23$. https://doi.org/https://dx.doi.org/10.18592/tarbiyah.v7i1.2100.

Zuliani, D., Florentinus, T. S., \& Ridlo, S. (2017). Pengembangan Instrumen Penilaian Karakter pada Siswa Kelas IV Sekolah Dasar. Journal of Research and Educational Research Evaluation, 6(1). https://doi.org/https://doi.org/10.15294/jrer.v6i1.16207. 